IJ§ER

ISSN: 2149-5939
International Journal of Social Sciences and Education Research

Online, http://dergipark.gov.tr/ijsser

Volume: 3(2), 2017

\title{
Chemical Castration as a security measure in the criminal legislation of the Republic of Macedonia
}

\author{
Vedije Ratkoceri 1 \\ Received Date: 01 / 09 / 2016 \\ Accepted Date: 15 / 01 / 2017
}

\begin{abstract}
Protecting children from sexual violence represents one of the basic premises of any state of contemporary society. It is quite necessary to take all necessary measures to prevent these criminal acts. The Republic of Macedonia last few years has taken a series of legislative measures aimed at preventing and punishing the most severe offenders of sexual assault against children. Taking only harsh punishments and repressive measures against the perpetrators are not enough for the prevention of sexual assault offenses against children. Those persons should be treated medically in order not to repeat the offense. Chemical castration is considered as most appropriate form of treatment of pedophiles in the world. In 2014 The Republic of Macedonia made a step further by incorporating in its criminal legislation, the pharmacological-medical treatment of perpetrators of sexual assaults against a child who has not attained the age of 14 a.k.a. chemical castration. This article aims to theoretically elaborate this measure as it is regulated in the Criminal Code and in the Law on the Execution of Criminal Sanctions by analyzing the respective articles in order to see the manner, the conditions and the circumstance of its regulation and execution.
\end{abstract}

Keywords: Chemical castration, security measures, criminal legislation, pedophilia

\section{Introduction}

Our criminal legislation provides four types of criminal sanctions which can be imposed on crime offenders: penalties, alternative measures, security measures and educational measures. While penalties and alternative measures are set for adult perpetrators of criminal acts, educational measures are envisaged for juvenile offenders and include juvenile sentence and institutional measures. Security measures are of a slightly different nature.

\section{Chemical Castration as a security measure}

Appearance of security measures as a pure preventive sanctions, reserved for pathological cases of criminality and developed based on the idea of the risk of the offender and measures for the protection of society from such a dangerous situation gained legislative expression in criminal law from the beginning of the twentieth century through the moderate variant of dualism of criminal sanctions and "double lane" of criminal law (Kambovski, Komentar na Krivicniot Zakonik na Republika Makedonia, 2015). Therefore, security measures are imposed in addition to penalties and aim to eliminate the dangerous situation in which the perpetrator has committed the offense. According to the Article 60 of the Criminal Code of the Republic of Macedonia, the purpose of security measures is to avoid situations or conditions that may affect the future perpetrator in committing criminal acts.

Until 2014 Criminal code foresaw three security measures (Article 61):

1. Mandatory psychiatric treatment and placement in a health institution;

${ }^{1}$ South East European University -TETOVO, MACEDONIA, v.ratkoceri@seeu.edu.mk 
Ratkoceri, V. (2017). Chemical Castration as a security measure in the criminal legislation of the Republic of Macedonia. International Journal of Social Sciences and Education Research, 3(2), 356-360.

2. Mandatory psychiatric treatment in freedom; and

3. Mandatory treatment of alcohol and drug addicts.

The court may impose one or more security measures to the perpetrator when there are fulfilled the conditions envisaged by the Criminal Code (Article 62, paragraph 1).

Thus, offenders who have committed the offense on mentally or substantially diminished responsibility, the court will appoint mandatory psychiatric treatment and placement in a health institution if it is proved that because of that condition he needs a medication and placement in such institution (Article 63, parag.1).

Perpetrator who has committed a criminal offense in the state of irresponsibility, the court may appoint mandatory psychiatric treatment in freedom if it finds that due to such situation he may again commit a criminal offense (Article 64).

To the perpetrator, who because of the use of permanent and addiction to alcohol, drugs and other psychotropic substances when there is a risk because of this dependency to further committing criminal acts, the court may impose mandatory treatment (Article 65). With the Amendments to the Criminal Code in February 2014 it was introduced a new security measure called "Medicalpharmacological treatment", which is also known as "chemical castration". This measure in the form of medical treatment was introduced in our legislation in order to reduce the cases of pedophilia, in particular to serve as prevention of recidivism for these offenses. The Criminal Code of the Republic of Macedonia in the Article 65-a states that to the perpetrator of sexual assault against a child under 14 years old, when there is a risk of further commitment of such offenses, the Court can impose a measure of medical-pharmacological treatment (paragraph 1). So, this measure is provided only for the criminal offense "Sexual assault against a child who has not attained 14 years" provided in the Article 188 of the Criminal Code.

The term "chemical castration" describes a medical treatment that uses anti hormonal drugs to block the release of hormones, resulting in significantly lower testosterone levels and sex drives in men (Murray, 1998). Chemical castration is used to reduce sexual urges. This type of castration is performed by taking a class of drugs called anti-androgens in tablet or injection form and does not involve the removal of the testes (Russell, 1997). A question that often arises in relation to sexual abusers is whether they are mentally ill or criminals. The presence of "Pedophilic Disorder" in the DSM-5 suggests that at least one committee believed that child sexual abuse is a mental disorder (Blackman \& Dring, 2016). That's why in certain legislations chemical castration has been introduced as a sanction (USA, Poland, Estonia etc.) while in others (Great Britain, Germany etc.) is used as a medical therapy for perpetrators of sexual acts with their consent (Kambovski, Komentar na Krivicniot Zakonik na Republika Makedonija, 2015).

Beside chemical castration, some states (for example Czech Republic) use surgical castration (which involves removal of organs) to treat pedophiles.

Chemical castration is one of the most effective and least restrictive ways to help treat child predators and keep children safe (Tullio, Chemical Castration for Child Predators: Practical, Effective, and Constitutional, 2009).

In our legislation the imposition of this measure needs the consent of the perpetrator of the criminal offense, so, it is on a voluntary basis. "Compensation" for voluntary submission to such medical treatment is the reduce of the sentence of imprisonment, respectively, the perpetrator will 
Ratkoceri, V. (2017). Chemical Castration as a security measure in the criminal legislation of the Republic of Macedonia. International Journal of Social Sciences and Education Research, 3(2), 356-360.

serve half of the sentence. For instance, if for the criminal act is sentenced life imprisonment, the court may impose to the offender a sentence to imprisonment of 40 years; if for the criminal act imprisonment of 40 years is sentenced, the Court may impose to the offender a sentence of 20 years of imprisonment; and if criminal act is punishable by 20 years of prison, the court may impose the minimum prison sentence prescribed for that criminal act as long as the perpetrator agrees to undergo chemical castration treatment, which will last until the end of his life or until the Court estimates that is necessary to take the treatment (paragraph 2, 3 and 4 of the Article 65a of the Criminal Code) .

Unlike the other security measures in our legislation, which are executed before serving the eventual prison sentence, the pharmacological-medical treatment will be executed after the perpetrator serves the prison sentence, meaning after the perpetrator has been released in freedom. The chemical castration will be performed in the specialized medical institutions. Supervision for the implementation of the treatment will be performed by the Directorate on Execution of Sanctions who will inform the court at least once in 6 months regarding the execution of this measure and the need for the continuation or discontinuation of the treatment (paragraph 5 of the Article $65-\mathrm{a})$.

Whereas, in principle, the application of the chemical castration is on a voluntary basis with the consent of the perpetrator, the application may be converted into mandatory in cases when the perpetrator will not undergo chemical castration or willingly abandons the treatment after giving the consent and serving the sentence. In these cases the court can determine that the measure should be executed by force in the health institution or other specialized institution (paragraph 6).

Whereas, when dealing with recidivism, the court will order the mandatory chemical castration even without the consent of the offender (paragraph 7) but without further specifying whether in this case they will benefit dimidiation or any easements.

The procedure of execution of the security measure of medical-pharmacological treatment is regulated by the Law on the Execution of Criminal Sanctions of the Republic of Macedonia with the changes made to this law in November 2014 where as a novelty was incorporated an entire chapter, Chapter XXI-a titled "Medical-pharmacological treatment of perpetrators of the offense sexual assault against a child who has not attained 14 years".

This law regulates which institutions are responsible for the execution of this measure, who has the obligation to supervise the execution of this measure, how is the procedure of execution and other relevant issues regarding chemical castration. This law states that the treatment will be done in specialized medical institutions.

A Directive by the Minister of Health, as indicated in law will arrange which are these institutions and the way how this procedure shall be done (Article 257-a). The Law confirmes that the supervision of the execution of the chemical castration should be done by the Directorate on Execution of Sanctions in corporation with Corrective institutions - prisons and specialized medical institutions. Corrective institutions are obligated to send the court decision to the Directorate for Execution of Criminal Sanctions immediately after the beginning of prison sentence of the convicted person, (Article 257-b). The way how this data will be submitted more closely will be regulated with an additional Act from the Minister of justice (Article 257-b). Furthermore, this Directory sends the verdict to the specialized medical institution before commencing the 
Ratkoceri, V. (2017). Chemical Castration as a security measure in the criminal legislation of the Republic of Macedonia. International Journal of Social Sciences and Education Research, 3(2), 356-360.

preliminary stage for the release of the convicted person for the purpose of performing the analysis and preparation for the medical-pharmacological treatment (Article 257-b (2)).

For the initiation and the course of the enforcement of the medical-pharmacological treatment, the specialized medical institution has an obligation to inform the Directorate for Execution of Criminal Sanctions every six months, while this Directory may request further information from the medical institution beyond this period about the health condition of the person to whom this measure is applied and the results from the application of the measure, whereas, on the other hand the Directorate for Execution of Criminal Sanctions informs the court at least once in six months about the measure execution or about the need of its extension or termination (Article 257-v).

In circumstances when the person who has to undergo the treatment does not appear in the treatment for reasonable grounds, it is obliged to justify his absence within three days from the day when it had to undergo this treatment in the specialized medical institution, and for it to notify the institution. After receiving the excuse, the medical institution appoints a new term for the implementation of this measure and notifies the Directorate for Execution of Sanctions.

The specialized medical institution has the option to postpone the medical-pharmacological treatment if the person brings evidence for another hospital treatment or in a case of death occurred to close family member. This delay can last maximum until the end of the hospitalization, respectively up to 3 days after the death of a close family member ( Article 257d). In addition, the person who must undergo this treatment, has an obligation to inform the specialized medical institution for any change of address of residence (Article $257-\mathrm{g}$ ).

If the convicted person wont undergo the treatment for unjustified reasons or if exceeds three days from the day when it had to appear to the medical institution, the institution is obliged within 48 hours to inform the Department for execution of criminal sanctions. For this kind of refusal or leaving the treatment, the Directory, without delay will inform the competent court. In order to execute the measure, the Court without delay will order his bringing by force and this order will be submited to the police. If the person is unreached for the authorities, the court will realise a warrant for arrest (Article 256- gj). All expenses for the execution of the medical-pharmacological treatment will be on the burden of the Budget of the Republic of Macedonia ( Article 257 -e).

Directorate for Execution of Criminal Sanctions shall establish and maintain separate records of convicted persons to whom is pronounced the measure of medical-pharmacological treatment. Minister of Justice determines the form, content and manner of these data (Article 257 - zh).

\section{Conclusion}

With the incorporation of the chemical castration in its criminal legislation, Macedonia became the first country in the region that fights pedophilia with a medical treatment. The relevant articles that were analyzed in this paper satisfactorily regulate the issue of chemical castration of pedophiles, but also show us some deficiencies as follows:

Firstly, Chemical castration is prescribed only for the criminal act described in the Article 188 "sexual assault against a child who has not attained the age of $14 "$.

Secondly, the specialized medical institutions are not assigned yet, as well as the chemical castration procedure is unknown, here including the medicament that will be used for this procedure since there hasn't been issued yet a Directive by the Minister of Health. 
Ratkoceri, V. (2017). Chemical Castration as a security measure in the criminal legislation of the Republic of Macedonia. International Journal of Social Sciences and Education Research, 3(2), 356-360.

Thirdly, the Minister of Justice hasn't declared yet the Act which will regulate the collection of data from prisons and medical institutions for persons who must undergo this treatment after completing prison sentence.

Lastly, a high concern remains whether this measure is consistent with the fundamental human rights and dignity.

Until today, the measure of chemical castration is not yet imposed in the courts of the Republic of Macedonia.

\section{References}

Blackman, S. \& Dring, K. (2016). - Sexual aggression against children: Pedophiles' and abusers', Development, Dynamics, Treatability and the Law; Routledge, ISBN:978-1-138-92416-1 (hbk) ; ISBN:9781-138-92417-8 (pbk).

Kambovski,V. (2015). Komentar na Krivicniot Zakonik na Republika Makedonija, Second edition, Matica, Skopje 2015

Murray, (1998). California's Chemical Castration Law: A Model for Massachusetts? Criminal and Civil Confinement [Vol. 24:729] Available at: http://offerofproof.net/wp-content/uploads/24.2.Murray.pdf

Official Gazette of Republic of Macedonia (2014). Law on Amendments and Addendums of the Criminal Code, No. 27.

Official Gazette of Republic of Macedonia (2014). Law on Amendments and Addendums of the Criminal Code, No. 166/2014.

Russell, S. (1997). "Castration of repeat sexual offenders: an international comparative analysis". Houston Journal of International Law, 1997, ISSN: 0194-1879.

Tullio, E.M. (2009). Chemical Castration for Child Predators: Practical, Effective, and Constitutional, 13 CHAP. L. REV. 191 Available at: http://digitalcommons.chapman.edu/chapman-law-review/vol13/iss $1 / 7$

Zachary E. O. (2013). "Off with His __": Analyzing the Sex Disparity in Chemical Castration Sentences, 19 Mich. J. Gender \& L. 471 Available at: http://repository.law.umich.edu/mjgl/vol19/iss2/5 